\title{
Transformation of a flocculating Saccharomyces cerevisiae using lithium acetate and pYAC4
}

\author{
ARMANDO VENÂNCIO, LUCÍLIA DOMINGUES and NELSON LIMA
}

(Received 27 July 1998/Accepted 23 September 1998)

A flocculating yeast Saccharomyces cerevisiae ura3 was transformed by the method based on treatment of intact cells with lithium acetate plus single-stranded carrier DNA using the shuttle vector pYAC4. The transformation efficiency was above $10^{3}$ transformants per microgram of plasmid DNA which is similar to other described yeast transformation systems. Under selective pressure, the transformed cells were stable and maintained the flocculation ability. Thus, this simple transformation system can be used for gene expression studies in flocculating yeasts, overcoming disadvantages of conventional methods such as the spheroplast one.

Several methods to transform DNA into yeast cells are currently available, such as transformation of spheroplasts made with lytic enzymes (HINNEN et al. 1978; BEGGS 1978), transformation of intact cells made competent either by lithium acetate (ITO et al. 1983, SCHIESTL and GIETZ 1989) or by electroporation (MANIVASAKAM and SHIESTL 1993). To our knowledge, there are no published methods for preparing pYAC clones using transformation protocols with the lithium acetate method (BURKE and OLSON 1991).

Yeast flocculation, defined as the aggregation of yeast cells into flocs or clumps which sediment rapidly in culture medium, is one of the most important properties of yeast strains used in traditional processes like brewing and winemaking. It might also be useful in modern biotechnology for the production of heterologous proteins and it has already shown its value in the development of continuous fermentation processes (TEIXEIRA et al. 1990) having a strong influence on the process overall performance. On one hand, it allows for the operation in a continuous mode at high cell concentration, thus increasing system overall productivity. On the other hand, biomass concentration in the effluent is reduced, thus decreasing product separation/purification costs.

The flocculent yeast strain used in this work is a Saccharomyces cerevisiae strain with an ura3 gene constructed by ultraviolet mutagenesis and tested for its resistance towards 5-fluoro-orotic acid. The use of pYAC4 plasmid - a yeast artificial chromosome shuttle vector containing the yeast URA3 gene as selectable marker - to transform intact Saccharomyces cerevisiae cells using lithium acetate and single-stranded carrier DNA is reported (VENÂNCIO et al. 1995).

\section{Materials and methods}

Strains and media: The flocculent wild-type (WT) haploid strain of S. cerevisiae NCYC869 was mutagenized by ultraviolet radiation and ura3 mutants were isolated by positive selection using 5-fluoro-orotic acid as described previously (LiMA et al. 1995). An auxotrophic strain A3 (MATa FLO1 ura3) was used for transformation experiments. Escherichia coli HB101 (Bio-Rad) was used for all bacterial transformations and plasmid propagations. Yeast strains were cultured in complete YEPD medium ( $2 \%$ glucose, $2 \%$ peptone, $1 \%$ yeast extract) or minimal SD medium ( $2 \%$ glucose, 
$0.67 \%$ yeast nitrogen base without amino acids) at $30{ }^{\circ} \mathrm{C}$ on a reciprocal shaker at $150 \mathrm{rpm}$. To grow A3 auxotrophic mutant, SD medium with appropriate supplement $(50 \mu \mathrm{g} / \mathrm{ml}$ uracil) was used. E. coli $\mathrm{HB} 101$ was grown in $\mathrm{LB}$ medium (1\% casein, $0.5 \%$ yeast extract, $0.5 \% \mathrm{NaCl})$. Ampicillin was used as selective antibiotic at a concentration of $100 \mu \mathrm{g} / \mathrm{ml}$. Solidified media contained $1.5 \%$ of agar.

Plasmid: Plasmid pYAC4 was purchased from SIGMA (V-0758, Lot 103H6770). This shuttle vector contains pBR322 + CEN4 + TEL + ARS1: TRP1 + URA3 (BURKE et al. 1987).

E. coli transformation and other procedures: E. coli was transformed by electroporation using a Bio-Rad E. coli Pulser Apparatus according to protocols from the supplier. Plasmid isolation from E. coli was performed with a Qiagen-tip 20 commercial kit from DIAGEN GmbH and used as described by the supplier.

Yeast intact cells transformation: The transformation procedure used was based on the treatment of intact cells with lithium acetate using single-stranded nucleic acids (ss-DNA) as carrier as described previously (ITO et al. 1983, SCHIESTL and GIETZ 1989) with minor modifications. The yeast cells were grown overnight in $25 \mathrm{ml} \mathrm{SD}$ plus uracil medium to a concentration of $5-10 \times 10^{6}$ cell $/ \mathrm{ml}$. The cells were collected by centrifugation, washed twice in TE (10 mM Tris-HCl, pH 7.5, 1 mM EDTA), ressuspended in $2 \mathrm{ml}$ of TE/LiAc solution (TE with $100 \mathrm{~mm}$ lithium acetate) and incubated for $1 \mathrm{~h}$ at $30{ }^{\circ} \mathrm{C}$. Up to $120 \mu \mathrm{g}$ of denatured salmon sperm carrier DNA was added and aliquots of $200 \mu \mathrm{l}$ were made using microfuge tubes. Transforming DNA was added to yeast suspension and incubated for $30 \mathrm{~min}$ at $30{ }^{\circ} \mathrm{C}$. Then, $700 \mu \mathrm{l}$ filter sterile $40 \%$ PEG 4000 solution (40\% PEG 4000 in TE/LiAc solution) was added and the tubes were incubated for $1 \mathrm{~h}$ at $30^{\circ} \mathrm{C}$. The cells were heat shocked for 10 min in a $42{ }^{\circ} \mathrm{C}$ waterbath, briefly centrifuged, washed with $500 \mu \mathrm{l}$ of TE solution, ressuspended in $500 \mu \mathrm{TE}$ and plated onto SD omission medium.

Yeast plasmid isolation: Transformant yeast cells were grown overnight in SD without uracil. Cells were collected by centrifugation and washed with distilled water. Then a $0.2 \mathrm{ml}$ solution of $2 \%$ Triton $\mathrm{X}-100,1 \%$ SDS, $100 \mathrm{~mm} \mathrm{NaCl}, 10 \mathrm{~mm}$ Tris-HCl, $\mathrm{pH} 8,1 \mathrm{~mm}$ EDTA was added to the cells pellet. After adding $0.2 \mathrm{ml}$ of phenol:chloroform:isoamyl alcohol $(25: 24: 1)$ and $0.3 \mathrm{~g}$ of acid-washed glass beads, this suspension was vortexed for 3-4 minutes. To this suspension, a $0.2 \mathrm{ml}$ of TE, $\mathrm{pH} 8$, was added. The suspension was centrifuged and the aqueous layer was transferred to a fresh tube, where precipitation with ethanol was carried out. Treatment with RNaseA was performed followed by ammonium acetate and ethanol precipitation. The recovered DNA was ressuspended in TE. This plasmid solution was used for electroporation of E. coli HB101. Plasmid DNA was isolated from E. coli, digested with EcoRI, BamHI and XhoI, and fractionated in a $0.7 \%$ agarose gel according to the standard method described elsewhere (SAMBROOK et al. 1989).

Plasmid stability and determination: Aliquots $(500 \mu \mathrm{l})$ were successively withdrawn from the YEPD tube cultures to new tubes every $24 \mathrm{~h}$ during 5 days. The cells of last aliquot were plated for single colonies onto YEPD agar plates after being washed twice with $1.5 \% \mathrm{NaCl}$ solution, $\mathrm{pH} 3.0$, to ensure floc dispersion. One thousand colonies were screened for plasmid loss by replicating them onto minimal SD agar plates.

Flocculation assay: Yeast cells were grown until stationary phase. After centrifugation, yeast cells were washed twice with a $1.5 \% \mathrm{NaCl}, \mathrm{pH} 3.0$, solution. A $24 \mathrm{ml}$ volume of cell suspension was placed on a $25 \mathrm{ml}$ graduated cylinder. Then, $1 \mathrm{ml}$ of a $100 \mathrm{mM} \mathrm{CaCl}_{2}, \mathrm{pH} 3.0$, was added and the solution was immediately mixed by inversion 18 times. Samples of $200 \mu \mathrm{l}$ were taken at the $20 \mathrm{ml}$ level at different time values. The sample OD value was read at $620 \mathrm{~nm}$ (SOARES et al. 1992). The normalized cell concentration defined as the ratio between actual and initial cell concentration was plotted against sedimentation time. A sedimentation profile was then obtained.

\section{Results and discussion}

The results of the transformation experiments are presented in Table 1. 
Table 1

Transformation of Saccharomyces cerevisiae

\begin{tabular}{lllcl}
\hline Strain & Genotype & Plasmid & $\begin{array}{l}\text { Carrier ss-DNA concentration } \\
(\mu \mathrm{g})\end{array}$ & $\begin{array}{l}\text { Transformation } \\
\text { frequency }\end{array}$ \\
\hline A3 & MATa FLO1 ura3 & no & 0 & - \\
& & pYAC4 & 0 & $2.7 \times 10^{1}$ \\
& & 30 & $3.3 \times 10^{3}$ \\
& & 60 & $2.5 \times 10^{3}$ \\
& & 120 & $8.8 \times 10^{2}$ \\
\hline
\end{tabular}

${ }^{\text {a }}$ Expressed as the total number per $1 \mu \mathrm{g}$ of plasmid DNA.

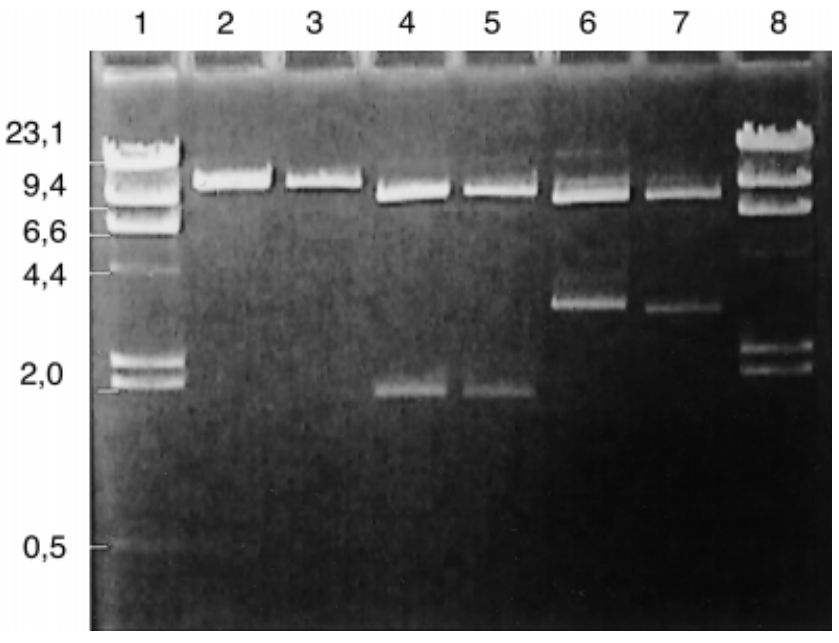

Fig. 1

Detection of plasmid DNA by agarose gel electrophoresis. Lane 1 and 8 , size marker (HindIII-digested $\lambda$-DNA) shown in $\mathrm{Kb}$; lane 2, 4 and 6 pYAC4 used for yeast transformation digested with EcoRI, Bam $\mathrm{HI}$ and $\mathrm{XhoI}$, respectively; lane 3,5 and 7 plasmid isolated from $S$. cerevisiae and recloned in E. coli HB101 digested with EcoRI, BamHI and $\mathrm{XhoI}$, respectively.

S. cerevisiae ura3 strain was transformed successfully to $\mathrm{Ura}^{+}$phenotype with pYAC4 plasmid showing a transformation efficiency higher than $10^{3}$ transformants per microgram of plasmid DNA which is similar to other described yeast transformation systems. The addition of single stranded DNA as a carrier increased the transformation efficiency by 100 fold, as noted by SCHIESTL and GIETZ (1989). In contrast the carrier concentration increase caused no significant improvement on the transformation efficiency. The optimal carrier concentration was found to be around $30 \mu \mathrm{g}$ and was used thereafter. The low stability of the $\mathrm{Ura}^{+}$phenotype (27\%) indicated the autonomous existence of the plasmid in the transformed cells of $S$. cerevisiae. This was confirmed by the ability of the isolated plasmid DNA from yeast transformants to transform $E$. coli to ampicillin resistance. The agarose gel electrophoresis analysis of the plasmids from E. coli transformants revealed that the plasmid pYAC4 can be used as a shuttle vector between E. coli and $S$. cerevisiae strains (Fig. 1).

The flocculence ability of cell transformants was not affected by the uptake of foreign DNA. In fact, the results obtained in the transformant flocculation assay, overlapped the ones obtained for the parental flocculent strains (Figs. 2 and 3). This result is of great importance in genetic manipulation of flocculent industrial yeast strains. It should be noted that in contrast to spheroplast transformation method which implies cell wall regeneration, the lithium acetate method avoids pertubation of cell walls. Therefore the flocculation capacity, which is a cell wall dependent phenomenon, is less prone to be affected by the lithium acetate method. 


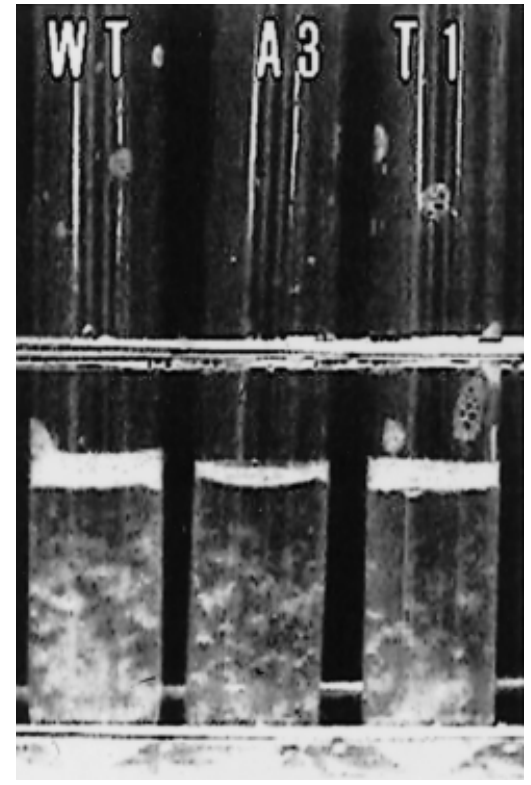

Fig. 2

Visual aspect of the flocculence ability from the strains: WT - S. cerevisiae NCYC869

A3 - S. cerevisiae NCYC869-A3

T1 - S. cerevisiae NCYC869 A3/pYAC4

In brief this study has demonstrated the feasibility of the transformation of Saccharomyces cerevisiae cells by the lithium acetate method plus single-stranded carrier DNA with a yeast artificial chromosome plasmid (pYAC4). This facilitates greatly the YAC manipulation required for a wide variety of applications. To our knowledge this is the first time that a flocculent Saccharomyces cerevisiae strain has been transformed. The present methodology will allow for genetic studies in flocculent strains such as those strains used in the brewing industry.

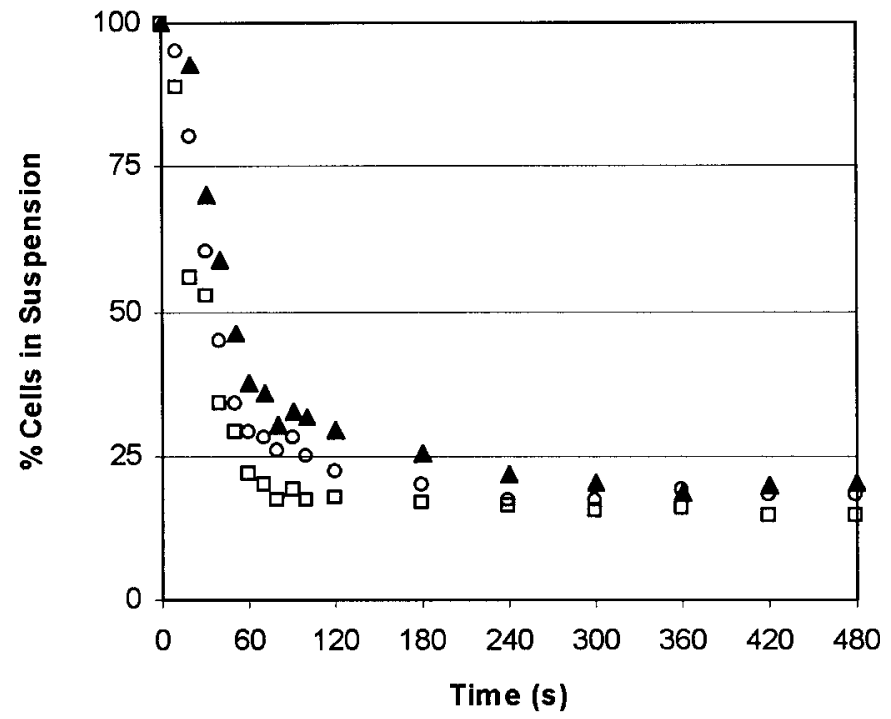

Fig. 3

Sedimentation profile obtained in the flocculation assay: -O- S. cerevisiae NCYC869 (WT);

- $\square-$ S. cerevisiae NCYC869A3 (A3);

-A- S. cerevisiae NCYC869A3/pYAC4 (T1).

The results presented are the mean of three independent assays. 


\section{Acknowledgements}

The authors wish to thank Prof. MANUEL Mota for his encouragement throughout the course of this work and for critically reading the manuscript. LUCílí DOMINGUES was supported by a grant PRAXIS XXI/BD/11306/97 from FCT (Fundação para a Ciência e Tecnologia), Portugal.

\section{References}

BEGGS, J. D., 1978. Transformation of yeast by a replicating hybrid plasmid. Nature, 275, 104-109.

BuRKe, D. T. and Olson, M. V., 1991. Preparation of clone libraries in yeast artificial chromosome vectors. Meth. Enzymol., 194, 251-270.

Burke, D. T., Carle, G. F. and Olson, M. V., 1987. Cloning of large segments of exogenous DNA into yeast by means of artificial chromosome vectors. Science, 236, 806-812.

HinNEN, A., Hicks, J. B. and FINK, G. R., 1978. Transformation of yeast. Proc. Natl. Acad. Sci. USA, 75, 1929-1933.

Ito, H., Fukuda, Y., Murata, K. and Kimura, A., 1983. Transformation of intact yeast cells treated with alkali cations. J. Bacteriol., 153, 163-168.

Lima, N., Moreira, C., TeiXeira, J. A. and Mota, M., 1995. Introduction of flocculation into industrial yeast, Saccharomyces cerevisiae saké, by protoplast fusion. Microbios, 81, 187-197.

ManivasaKam, P. and Schiestl, R. H., 1993. High efficiency transformation of Saccharomyces cerevisiae by electroporation. Nucleic Acids Res., 21, 4414-4415.

SAMbroOK, J., Fritsch, E. F. and Maniatis, T., 1989. Molecular Cloning: A Laboratory Manual (2nd Edn.), Cold Spring Harbor Laboratories, Cold Spring Harbor, NY.

SCHIESTL, R. H. and GIETZ, R. D., 1989. High efficiency transformation of intact cells using single stranded nucleic acids as a carrier. Curr. Genet., 16, 339-346.

SoARes, E. V., Teixeira, J. A. and Mota, M., 1992. Interaction between flocculent and nonflocculent cells of Saccharomyces cerevisiae. Can. J. Microbiol., 38, 969-974.

Teixeira, J. A., Mota, M. and Goma, G., 1990. Continuous ethanol production by a flocculating strain of Kluyveromyces marxianus: bioreactor performance. Bioprocess Eng., 5, 123-127.

VenÂNCIO, A., LiMA, N. and MotA, M., 1995. Genetic transformation of intact industrial flocculating yeast cells (Saccharomyces cerevisiae) by using lithium acetate and YAC4 plasmid. Yeast, 11 (Spec. Iss.), p. 607.

Mailing address: Prof. Dr. Nelson Lima, Centro de Engenharia Biológica, Universidade do Minho, 4700 Braga, Portugal

E-mail: nelson@iec.uminho.pt 